\title{
Linear Expansion and Durability of a Composite Boards (MDF Laminated Using Three Selected Wood Veneers) against Drywood Termites ${ }^{1}$
}

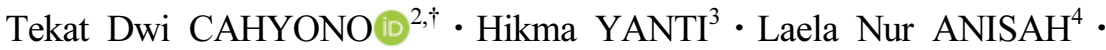 \\ Muh Yusram MASSIJAYA ${ }^{5} \cdot$ Apri Heri ISWANTO $^{6}$
}

\begin{abstract}
This research was conducted to investigate the linear expansion and resistance properties of a composite board (com-ply). This board was made of medium-density fiberboard (MDF) laminated using avocado (Persea americana), mahogany (Swietenia mahogani), and pine (Pinus merkusii) veneers. These three types of veneers were laminated on both surfaces of the MDF using adhesives, namely, epoxy and isocyanate. Glue $\left(250 \mathrm{~g} \cdot \mathrm{m}^{-2}\right)$ was spread on the surface, followed by cold press for $3 \mathrm{~h}$ with an applied pressure of $15 \mathrm{~kg} \cdot \mathrm{cm}^{-2}$. The research result revealed that com-ply exhibited an increased dimensional stability compared with MDF, indicated by reduction in water absorption, thickness swelling, and linear expansion. The com-ply made of the pine veneer and isocyanate adhesive exhibited high density, water absorption, thickness swelling, and screw withdrawal load. The com-ply that exhibited the strongest resistance to drywood termite attacks was the one made of the mahogany veneer and isocyanate adhesive. Moreover, the com-ply that exhibited the biggest weight loss (3.6\%) was made of the pine veneer and epoxy adhesive. The results of this research may facilitate in manufacturing com-ply using the selected veneer and adhesive without the application of hot press.
\end{abstract}

Keywords: com-ply, resistance, linear expansion, MDF, veneer

\section{INTRODUCTION}

Hundreds of millions meter cubic of wood-based panels are produced each year throughout the world. One of them is fiberboard. The fiberboard production growth increased by $44 \%$ within 2011-2014 period and $82 \%$ of the world's fiberboard production was medium density fiberboard (MDF). Since 2011, its production had grown on average $6 \%$ per year (FAO, 2016). China is the world's leading MDF producers

\footnotetext{
${ }^{1}$ Date Received April 16, 2020, Date Accepted November 6, 2020

${ }^{2}$ Faculty of Agriculture and Forestry, University of Darussalam Ambon, Jl. Raya Waehakila Puncak Wara, Sirimau, Ambon 97128, Indonesia

${ }^{3}$ Faculty of Forestry, Tanjungpura University, Jl. Prof. Hadari Nawawi, Pontianak 78121, Indonesia

${ }^{4}$ Indonesian Ministry of Environment and Forestry, Manggala Wanabakti Building, Jl. Jend. Gatot Subroto, Jakarta 10270, Indonesia

${ }^{5}$ Department of Forest Product, Faculty of Forestry, IPB University, Jl. Raya Dramaga, Bogor 16680, Indonesia

${ }^{6}$ Department of Forest Product, Faculty of Forestry, Universitas Sumatera Utara, Padang Bulan, Medan 20155, Indonesia

$\dagger$ Corresponding author: Tekat Dwi CAHYONO (e-mail: tekatdwicahyono@gmail.com, ORCID: 0000-0002-3010-7656)
} 
Tekat Dwi CAHYONO $\cdot$ Hikma YANTI $\cdot$ Laela Nur ANISAH • Muh Yusram MASSIJAYA $\cdot$ Apri Heri ISWANTO

and users. Indonesia's fiberboard production in 2017 was $449,492.81 \mathrm{~m}^{3}$ (BPS, 2017). The strength of this product lied in its use of varied raw materials and industrial wastes (Hiziroglu et al., 2007; Garcia et al., 2018). In its production process, some MDF types were laminated with melamine, polyvinyl chloride, veneer and other materials to improve the surface appearance and other physical, mechanical qualities (Kılıç et al., 2009; Jocham et al., 2011; Taghiyari and Norton, 2014).

The veneer laminated to MDF surface is widely open in the future. This is because the world's woodbased panel production is still dominated by veneer and plywood. In 2015, its production had reached 171 million $\mathrm{m}^{3}$ (39\% of the total wood-based panel production), increasing $49 \%$ from 2011 (FAO, 2016). The veneer and plywood productions in Indonesia in 2017 were $4.8 \%$ and $11.1 \%$ respectively of the total woodbased panel (BPS, 2017). While raw material procurement might be an issue, it can be solved using the right approach, such as utilizing fast-growing woods (Rowell, 1998; Cahyono and Masssijaya, 2007; Cahyono et al., 2015). Moreover, previous studies on increased flexural properties after the process of laminated composite board with veneer had provided some support (Biblis et al., 1996; Büyüksarý et al., 2012; Cahyono et al., 2019).

This research manipulated MDF into composite board (com-ply) by adding avocado, pine and mahogany veneer on the face and back parts. Avocado veneer was available with affordable price but less frequently used as the laminating materials. Meanwhile, pine and mahogany veneer had more attractive and good appearance. Those three veneer types had good dimensional stabilization and were proven capable of improving the physical, mechanical, and durability properties when utilized to laminate the oriented strand board (Yanti et al., 2019). Com-ply improved the benefits of panel products into structural materials and expanded its utilization. This research aimed at evaluating comply physical properties, linear expansion, internal bonding, screw withdrawal load and resistance against drywood termite's attack. The research results provided alternative attempts to improve MDF's surface appearance, physical properties, strength and durability against biological destruction agent attack.

\section{MATERIALS and METHODS}

\subsection{Materials}

Medium density fiberboard (MDF) used in this research was produced by the Indonesia Fiberboard Industry Ltd. The board obtained from the local market had the size of $244 \mathrm{~cm} \times 122 \mathrm{~cm} \times 1 \mathrm{~cm}$ (length, width, thickness). The adhesive for MDF consisted of phenol formaldehyde and solid content adhesive of $42.5 \pm 2 \%$. The MDF laminating materials were avocado (Persea americana), mahogany (Swietenia mahogany), and pine (Pinus merkusii) veneers. Those three veneers were obtained from the local market and the veneer thickness was $1.52 \pm 0.08 \mathrm{~mm}$. The moisture content of veneer and MDF before adhered was respectively by $7.4 \pm 0.62 \%$ and $12.2 \pm 1.2 \%$. The density of pine, mahogany and avocado veneer was respectively $587 \pm 23.22 \mathrm{~kg} \cdot \mathrm{m}^{-3}, 516 \pm 35.19 \mathrm{~kg} \cdot \mathrm{m}^{-3}$, and $543 \pm 14.21$ $\mathrm{kg} \cdot \mathrm{m}^{-3}$.

The adhesives used were isocyanate and epoxy. Both adhesives consisted of base and hardener with the composition of 100:12 for isocyanate and 100:100 for epoxy. The base type and hardener of isocyanate adhesive were respectively PI-127T and H3M. Both adhesive types were produced by Poly Oshika Ltd. and the Solid Content was respectively $43 \pm 3 \%$ and $98 \pm$ $0.5 \%$. The viscosity of PI- $127 \mathrm{~T}\left(\mathrm{ps} / 25{ }^{\circ} \mathrm{C}\right)$ was 150 ps and 1.5 ps for H3M. Epoxy Adhesive used the base type of AD-102 and hardener type of VR-502. Those adhesives were made by Fox Ltd. 
Linear Expansion and Durability of a Composite Boards (MDF Laminated Using Three Selected Wood Veneers) against Drywood Termites

\subsection{Development of composite board}

Table 1 showed the composition of the veneer and adhesives. Each type of veneers was used to laminate both MDF (face and back) surfaces with a combination of two types of adhesive. The test sample size was $35 \mathrm{~cm} \times 35 \mathrm{~cm}$ and the adhesive glue spread was $250 \mathrm{~g} \cdot \mathrm{cm}^{-2}$. Cold press was applied for 3 hours at 15 $\mathrm{kg} \cdot \mathrm{cm}^{-2}$ press pressure. Afterwards, a conditioning was applied for two weeks and followed with test sample cutting based on each testing standard. Conditioning was conducted at the room temperature $\left(25^{\circ} \mathrm{C}\right)$ and relative humidity $(\mathrm{RH}) 85 \%$.

Table 1. Com-ply Types

\begin{tabular}{cccc}
\hline Num. & Type & Adhesive & $\begin{array}{c}\text { Face and Back } \\
\text { Veneer }\end{array}$ \\
\hline \hline 1 & MDF & - & - \\
2 & AMI & Isocyanate & Avocado \\
3 & AME & Epoxy & Avocado \\
4 & PMI & Isocyanate & Pine \\
5 & PME & Epoxy & Pine \\
6 & MMI & Isocyanate & Mahogany \\
7 & MME & Epoxy & Mahogany \\
\hline
\end{tabular}

\subsection{Testing of physical and mechanical properties}

The testing of physical properties was conducted on density, moisture content, water absorbtion, thickness swelling and linear expansion (parallel and perpendicular). Density was measured based on the oven-dry weight, while the test sample's length and width were $10 \mathrm{~cm} \times 10 \mathrm{~cm}$. The test sample's moisture content and water absorption were $10 \mathrm{~cm} \times 10 \mathrm{~cm}$ (length, width), while the test sample's thickness swelling and linear expansion were $5 \mathrm{~cm} \times 5 \mathrm{~cm}$ (length, width). Next, the mechanical properties tested was screw withdrawal load (SWL) and internal bonding (IB). The used standard was JIS A 5905-2003 (JSA, 2003). The
SWL test sample's length and width were $5 \mathrm{~cm} \times 10$ $\mathrm{cm}$, while the IB test sample's length and width were $5 \mathrm{~cm} \times 5 \mathrm{~cm}$.

\subsection{The durability of com-ply to the drywood termites' attacks}

The testing of resistance to drywood termites (Cryptotermes cynocephalus) was performed based on SNI 01-7207-2006 standard (BSN, 2006). Fifty worker termites were placed in a glass tube in all com-ply surfaces. The test sample size used was $2.5 \mathrm{~cm} \times 5.0$ cm (length and width), and the thickness followed the com-ply thickness. The com-ply resistance to termites attack was analyzed based on the weight loss percentage and the drywood termite mortality for 12 weeks feeding.

\subsection{Data analysis}

This research used completely randomized design with 7 treatments (com-ply types) and five repetitions. The general model of this design wasas presented by Gaspersz (1991). If the difference in com-ply types was significant, it was then followed with Duncan advanced test to see the best type.

\section{RESULTS and DISCUSSION}

\subsection{Moisture content and density}

The mean moisture content (MC) of all com-ply types, including MDF, was $12.32 \%$ at $1.33 \%$ standard deviation. The moisture content of each com-ply type was presented in Table 2 . The analysis of variance result showed that com-ply type had an influence on MC $(p=0.000)$. Table 3 shows com-ply had relatively high mean moisture content, including PMI (pine, isocyanate adhesives), AMI (avocado, isocyanate adhesives), and MME (mahony, epoxy adhesives). The 
Tekat Dwi CAHYONO $\cdot$ Hikma YANTI $\cdot$ Laela Nur ANISAH $\cdot$ Muh Yusram MASSIJAYA $\cdot$ Apri Heri ISWANTO

Table 2. Moisture content and density of com-ply

\begin{tabular}{ccc}
\hline Type of Com-ply & $\mathrm{MC}^{s}(\%)$ & $\mathrm{D}^{s}\left(\mathrm{~kg} \cdot \mathrm{m}^{-3}\right)$ \\
\hline \hline MDF & $12.22 \pm 0.39$ & $653 \pm 14.63$ \\
MMI & $13.36 \pm 0.22$ & $619 \pm 7.83$ \\
MME & $10.57 \pm 0.45$ & $650 \pm 20.87$ \\
AMI & $13.60 \pm 0.90$ & $621 \pm 5.55$ \\
AME & $11.93 \pm 0.46$ & $632 \pm 5.57$ \\
PMI & $13.63 \pm 0.32$ & $695 \pm 16.80$ \\
PME & $11.04 \pm 0.40$ & $678 \pm 16.25$ \\
\hline
\end{tabular}

$s=$ significance $(p \leq 0.05)$

Table 3. Duncan analysis for moisture content

\begin{tabular}{cccccc}
\hline \multirow{2}{*}{$\begin{array}{c}\text { Type of } \\
\text { Com-ply }\end{array}$} & $\mathrm{N}$ & \multicolumn{5}{c}{ Subset } \\
\cline { 3 - 6 } & & 1 & 2 & 3 & 4 \\
\hline \hline MMI & 5 & 10.5680 & & & \\
PME & 5 & 11.0420 & 11.0420 & & \\
AME & 5 & & 11.9340 & 11.9340 \\
MDF & 5 & & & 12.2180 \\
PMI & 5 & & & & 13.2740 \\
AMI & 5 & & & & 13.6040 \\
MME & 5 & & & & 13.6040 \\
\hline Sig. & & 0.307 & 0.060 & 0.538 & 0.501 \\
\hline
\end{tabular}

Means for groups in homogeneous subsets are displayed. Based on observed means.

The error term is Mean Square (Error) $=0.518$.

laminating veneer thinner than MDF was easier to reach the Equilibrium Moisture Content. Furthermore, the com-ply types of MMI (mahony, isocyanate adhesives), PME (pine, epoxy adhesives) and AME (avocado, epoxy adhesives) seen having smaller MC when compared to MDF. The addition of adhesive between veneer and MDF resulted in the com-ply's hygroscopic changes. The isocyanate adhesive was bonded with the wood hydroxyl group that its reactivity decreased (Nuryawan and Alamsyah, 2017). Beside those factors, the moisture content of composite board was influenced by density and the MC raw materials.

The com-ply density increased the laminated pine veneer ranging between $2.7 \%$ and $7.7 \%$. The analysis of variance result indicated that veneer layer addition influenced density $(p=0.000)$. Duncan advanced test
Table 4. Duncan analysis for density

\begin{tabular}{|c|c|c|c|c|c|}
\hline \multirow{2}{*}{$\begin{array}{l}\text { Type of } \\
\text { Com-ply }\end{array}$} & \multirow{2}{*}{$\mathrm{N}$} & \multicolumn{4}{|c|}{ Subset } \\
\hline & & 1 & 2 & 3 & 4 \\
\hline MMI & 5 & $6.1880 \mathrm{E} 2$ & & & \\
\hline AMI & 5 & $6.2060 \mathrm{E} 2$ & & & \\
\hline AME & 5 & $6.3240 \mathrm{E} 2$ & $6.3240 \mathrm{E} 2$ & & \\
\hline MME & 5 & & $6.5040 \mathrm{E} 2$ & $6.5040 \mathrm{E} 2$ & \\
\hline $\mathrm{MDF}$ & 5 & & & $6.5340 \mathrm{E} 2$ & \\
\hline PME & 5 & & & & $6.7840 \mathrm{E} 2$ \\
\hline PMI & 5 & & & & $6.9540 \mathrm{E} 2$ \\
\hline Sig. & & 0.195 & 0.073 & 0.759 & 0.090 \\
\hline
\end{tabular}

Means for groups in homogeneous subsets are displayed. Based on observed means.

The error term is Mean Square (Error) $=233.929$.

placed com-ply PMI as the greatest increase mean than the other types (Table 4). The laminated veneer to composite board surface was more likely to increase the density although there was a same value with MDF and even there was a lower one. It was because of the different materials used as the layer (Yanti et al., 2019). Pine has the highest density as compared to avocado and mahogany (Karlinasari et al., 2010). The second causes were gluing and pressing during production process (Zhang et al., 2018; Cahyono et al., 2020). The adhesive addition might add the com-ply's weight, while the compression had the potential to change the density when changing the material properties, such as the occurrence of densification. These phenomena formed due to the mechanical power and interaction between adhesive and wood cells. Cristescu (2006) explained that during the compression process, most fibers located in the area of gluelines lost their luminary, approximated each other, and resulted in higher density.

\subsection{Water Absorption (WA), Thickness Swelling (TS) and Linear Expansion (LE)}

Water absorptions of MDF and com-ply are shown in Fig. 1. It was seen that MDF had greater WA than 


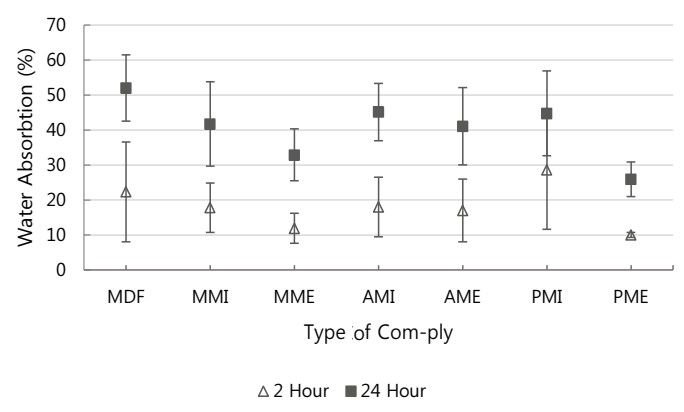

Fig. 1. Water Absorption of Com-ply.

the other 6 types. The analysis of variance result showed that com-ply type influenced WA during 24-hour immersion, with no influence occuring during 2-hour immersion. The Duncan test suggested that PME had the lowest WA than all com-ply types. Tsoumis (1991) has presented the fact that when wood is immersed in water, the active water movement may occur through the cell cavities. If the immersion is continuously made, the cell cavities will be saturated in water. Thus, the immersion period and density of the laminating materials contributed in WA difference.

The high mean thickness swelling (TS) value was dominated by MDF and PMI type com-ply (pine veneer, isocyanate adhesive). This type even had greater TS value than MDF in 2-hour immersion, even though after 24-hour immersion, the opposite occured (Fig. 2). In 2-hour immersion, the lowest TS was found in MME type and after 24-hour immersion was found in PME. MDF laminating using pine veneer and epoxy adhesive (PME type) was able to reduce the value of TS up to $68 \%$. Some contradictive phenomena happened in PMI, while the TS decrease was only $4 \%$ at the end of 24-hour immersion. The phenomena started to be seen from the WA value which was bigger than the MDF value, especially when the 2-hour immersion was performed. During the 24-hour immersion, the WA value was more than $40 \%$.

After being immersed for two hours, it is found that the parallel linear expansion (PLE) value of AMI type

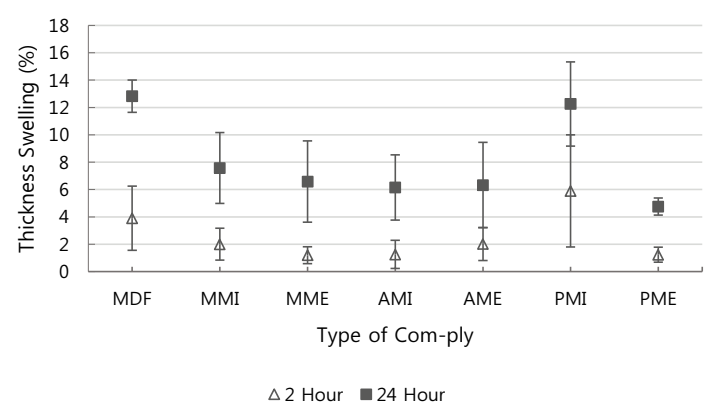

Fig. 2. Thickness swelling of com-ply.

com-ply is the higher than MDF and other com-ply (Table 5). Yet, after the immersion proceeds for 24 hours, MDF had the highest PLE. It was also seen the decreased PLE of MMI, MME, AMI and AME type com-ply after 2- and 24-hour immersions. Similar trend also occurred in perpendicular linear expansion (PpLE). Three com-ply types (MMI, AMI, PMI) had their PpLE increased and the other three had decreased after 2-hour immersion. After 24-hour immersion, MDF had the highest PpLE value. These increase and decrease in PLE and PpLE values were statistically insignificant, both during 2- and 24-hour immersions (Table 5).

The two main factors of LE were materials and manufacture process. The different wood types and particle orientations were the main causes of LE difference. It was the case particularly in composite panel comprising of particles $(\mathrm{Wu}$ and Suchsland, 1996; Iswanto et al., 2017). If the materials were relatively homogenous, for example fiberboard, then the LE difference was tightly related to the product density (Ganev et al., 2007; Ayrilmis, 2008). The manufacture process factors included adhesive type, thickness, and heat treatment (Xu and Suchsland, 1997; Miyamoto et al., 2002; Zhang et al., 2018).

Fig. 3 showed the linear regression between water absorption and thickness swelling. The relationship of these parameters was linear with a high determination value $\left(R^{2}=0.7964\right)$. The regression between water 
Tekat Dwi CAHYONO $\cdot$ Hikma YANTI $\cdot$ Laela Nur ANISAH $\cdot$ Muh Yusram MASSIJAYA $\cdot$ Apri Heri ISWANTO

Table 5. Water Absorption, Thickness Swelling and Linear Expansion of Com-ply

\begin{tabular}{cccccccccc}
\hline \multirow{2}{*}{$\begin{array}{c}\text { Type of } \\
\text { Com-ply }\end{array}$} & \multicolumn{2}{c}{ Water Absorption (\%) } & \multicolumn{2}{c}{ Thickness Swelling $(\%)$} & \multicolumn{4}{c}{ Linear Expansion } \\
\cline { 2 - 8 } & \multicolumn{2}{c}{$2^{n s}$ Hour } & $24^{s}$ Hour & $2^{s}$ Hour & $24^{s}$ Hour & $2^{n s}$ Hour & $24^{n s}$ Hour & $2^{n s}$ Hour & $24^{n s}$ Hour \\
\hline \hline MDF & $22.3 \pm 14.3$ & $52.0 \pm 9.5$ & $3.90 \pm 2.35$ & $12.82 \pm 1.17$ & $0.21 \pm 0.05$ & $0.52 \pm 0.07$ & $0.37 \pm 0.10$ & $0.86 \pm 0.25$ \\
MMI & $17.8 \pm 7.1$ & $41.8 \pm 12.0$ & $2.00 \pm 1.17$ & $7.57 \pm 2.59$ & $0.17 \pm 0.06$ & $0.38 \pm 0.08$ & $0.43 \pm 0.03$ & $0.68 \pm 0.19$ \\
MME & $12.0 \pm 4.3$ & $32.9 \pm 7.4$ & $1.20 \pm 0.62$ & $6.58 \pm 2.97$ & $0.18 \pm 0.13$ & $0.39 \pm 0.05$ & $0.33 \pm 0.11$ & $0.66 \pm 0.17$ \\
AMI & $18.0 \pm 8.5$ & $45.2 \pm 8.2$ & $1.26 \pm 1.03$ & $6.15 \pm 2.39$ & $0.26 \pm 0.07$ & $0.44 \pm 0.10$ & $0.45 \pm 0.18$ & $0.72 \pm 0.24$ \\
AME & $17.0 \pm 8.9$ & $41.1 \pm 11.0$ & $2.02 \pm 1.20$ & $6.33 \pm 3.11$ & $0.18 \pm 0.12$ & $0.39 \pm 0.10$ & $0.39 \pm 0.19$ & $0.73 \pm 0.27$ \\
PMI & $28.7 \pm 17.0$ & $44.8 \pm 12.1$ & $5.90 \pm 4.10$ & $12.26 \pm 3.08$ & $0.14 \pm 0.05$ & $0.30 \pm 0.08$ & $0.41 \pm 0.24$ & $0.81 \pm 0.12$ \\
PME & $10.0 \pm 0.7$ & $26.0 \pm 5.0$ & $1.24 \pm 0.55$ & $4.75 \pm 0.63$ & $0.22 \pm 0.07$ & $0.41 \pm 0.09$ & $0.38 \pm 0.09$ & $0.57 \pm 0.10$ \\
\hline
\end{tabular}

$s=$ significant $(p \leq 0.05)$

$n s=$ insignificant $(p>0.05)$

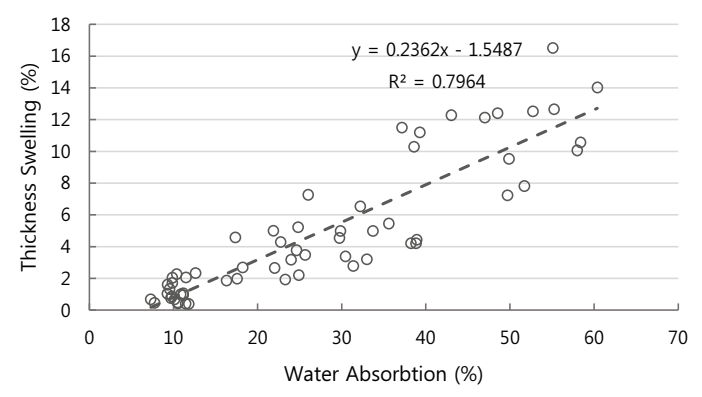

Fig. 3. Thickness Swelling of Com-ply based on Water Absorption Changes.

absorption and linear expansion (LE) was presented in Fig. 4. Both parameters seemed to influence each other since their $R^{2}$ values for, parallel and perpendicular ones, were 0.66 and 0.71 respectively. Furthermore, it might be seen that perpendicular LE had a greater value than the parallel one. The difference between the two was consistent in all com-ply types, during 2- and 24-hour immersions. The value difference for 2-hour immersion was $128.7 \pm 108.9 \%$ and for 24-hour immersion was less than that, i.e. $78.8 \pm 48.1 \%$. This percentage value confirmed the previous study's result which found that PpLE was greater than PLE (Wu and Suchsland, 1996).

Linear Expansion and TS occurred due to the

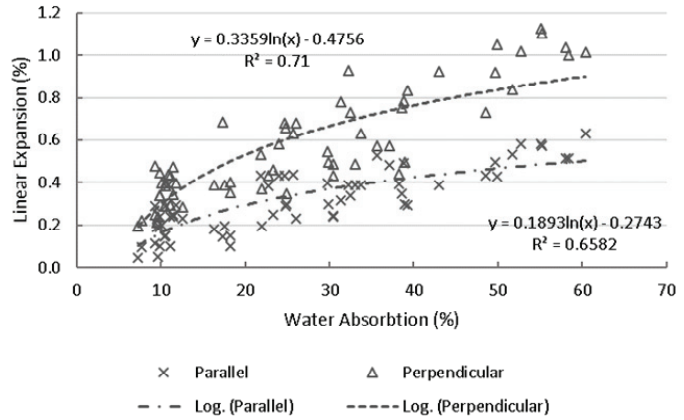

Fig. 4. Linear Expansion of Com-ply based on Water Absorption Changes.

changes of fiber walls in different MC conditions (Ganev et al., 2007). When explaining the influence of density on LE, in fact it was not congruent. Some presented that there was no relationship, such as in particleboard (Hiziroglu and Suchsland, 1993; Milagres et al., 2019), and MDF (Xu and Suchsland, 1997). However, some have presented the data in contradiction (Ayrilmis et al., 2017, Seo et al., 2019, Taskirawati et al., 2019). Thus, beside increasing the dimensional stability, the laminated MDF with avocado, mahogany, and pine veneer asserted a close relationship between WA and TS, especially the com-ply products. Second, the close relationship between WA and LE. Third, density changes influenced LE com-ply. 
Linear Expansion and Durability of a Composite Boards (MDF Laminated Using Three Selected Wood Veneers) against Drywood Termites

\subsection{Screw Withdrawal Load (SWL) and Internal Bonding (IB)}

Fig. 5 indicated the screw withdrawal load (SWL) difference between MDF and com-ply. MDF laminated using veneer was expected to contribute to SWL increase. In fact, one com-ply type (AMI type) was excluded from the standards while other com-ply values were above the standard which requires SWL value $>500 \mathrm{~N}$. The analysis of variance showed that com-ply type had an influence on SWL value ( $p=$ 0.000). Duncan test determined that PMI type com-ply had the highest SWL value, and the lowest one was AMI type (Avocado veneer, Isocyanate adhesive). Compared to MDF, the SWL increase of PMI type com-ply was $37.8 \%$. Other types had nearly similar means (Table 6). This result asserted that although one

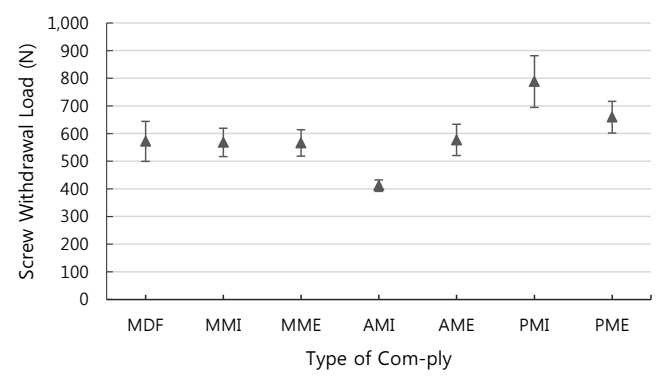

Fig. 5. Screw Withdrawal Load of Com-ply.

Table 6. Duncan analysis for Screw Withdrawal Load

\begin{tabular}{ccccc}
\hline \multirow{2}{*}{$\begin{array}{c}\text { Type of } \\
\text { Com-ply }\end{array}$} & $\mathrm{N}$ & \multicolumn{3}{c}{ Subset } \\
\cline { 3 - 5 } & & 1 & 2 & 3 \\
\hline \hline AMI & 5 & 30.9360 & & \\
MME & 5 & & 42.5260 & \\
MMI & 5 & & 42.6740 & \\
MDF & 5 & & 42.9805 & \\
AME & 5 & & 43.3380 & \\
PME & 5 & & 49.5320 & \\
PMI & 5 & & & 59.2280 \\
\hline Sig. & & 1.000 & 0.060 & 1.000 \\
\hline
\end{tabular}

Means for groups in homogeneous subsets are displayed. Based on observed means.

The error term is Mean Square (Error) $=26.017$.

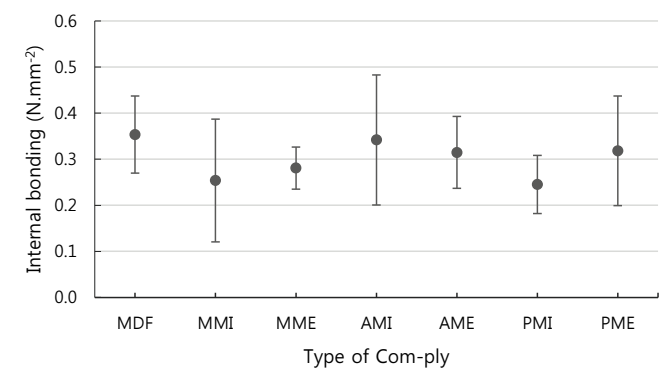

Fig. 6. Internal Bonding of Com-ply.

type was not included in standard, MDF laminating using avocado, mahogany and pine veneer was recommended to improve SWL.

MDF's internal bonding was $0.35 \pm 0.09 \mathrm{~N} \cdot \mathrm{mm}^{-2}$ and the IB of all com-ply types was $0.29 \pm 0.11 \mathrm{~N}$. $\mathrm{mm}^{-2}$. The complete values might be seen in Fig. 6 . All com-ply types had lower IB values than MDF, yet the differences were statistically insignificant $(p=$ 0.647). This was because during the testing, the part undergoing damage was the middle layer of composite board (MDF), thus it might be said that all those values were the IB value of MDF. The veneer parts glued using isocyanate and epoxy adhesive were not damaged. The requirement of minimum IB to meet JIS standard was $0.5 \mathrm{~N} \cdot \mathrm{mm}^{-2}$. Based on this requirement, all com-ply types in this research failed to meet the standards. Furthermore, low IB also gave the contribution to TS. Fig. 6 shows that PMI had the lowest IB. One of its implications was seen from the high WA and TS value.

\subsection{Resistance against drywood termites}

The wood and wood panel's resistance to drywood termites was classified into 5 categories (BSN, 2006). If the weight loss (WL) was less than $2 \%$, then it was classified as highly resistant. Weight losses between 2.0 and $4.4 \%$ were classified as resistant. Table 7 showed that MDF, MME, AMI and PME type com-ply were classified as resistant to attack, while 
Tekat Dwi CAHYONO $\cdot$ Hikma YANTI $\cdot$ Laela Nur ANISAH • Muh Yusram MASSIJAYA $\cdot$ Apri Heri ISWANTO

Table 7. Weight Loss and Mortality of all comp-ly types

\begin{tabular}{ccc}
\hline Type of Com-ply & Weight $\operatorname{Loss}^{n s}(\%)$ & Mortality $^{s}(\%)$ \\
\hline \hline MDF & $2.6 \pm 0.6$ & $98.0 \pm 3.1$ \\
MMI & $1.6 \pm 0.6$ & $94.8 \pm 8.5$ \\
MME & $2.1 \pm 0.5$ & $96.4 \pm 2.3$ \\
AMI & $2.4 \pm 0.2$ & $86.8 \pm 7.0$ \\
AME & $1.7 \pm 0.3$ & $92.8 \pm 4.1$ \\
PMI & $2.0 \pm 0.3$ & $87.2 \pm 8.8$ \\
PME & $3.6 \pm 2.5$ & $76.0 \pm 10.4$ \\
\hline
\end{tabular}

$s=$ significant $(p \leq 0.05)$

$n s=$ insignificant $(p>0.05)$

other types were classified as highly resistant.

During the test of resistance, drywood termites were placed on the test sample surface. As an implication, the laminated material constitutes the main factor which influenced its resistance to termites attack. The veneer of the three wood types used to laminate MDF might endure the attack level well. It was proven that the com-ply type of MMI (mahogany, isocyanate adhesives) had smaller weight loss. The MDF was laminated using avocado veneer and epoxy adhesive (AME type) increase the durability of MDF from resistant to highly resistant category. Com-ply types of AMI, PMI, and MME also had WL which was smaller than MDF. The only com-ply having WL higher than MDF was PME. However, the decreasing value of WL was statistically insignificant. The WL differences in the same wood types were caused by the veneer conditions. The pine wood part closing to the pith had the WL of more than $2 \%$, while the part closing to the bark, the value was less than $2 \%$. The durability of Mahogany wood from the drywood termites' attacks was categorized into highly resistant (WL $<2 \%$ ) both in heartwood and sapwood part (Septiana et al., 2014)

After attacking the surface, the termite would slowly attack the inside part. Isocyanate and epoxy adhesives served the purpose of making a hindrance in case the attack began to take place to the com-ply's middle part. The termite attack activities were inhibited as shown from the mortality which was more than $70 \%$. It was asserted with the termite mortality which was statistically significant $(p=0.002)$.

\section{CONCLUSION}

Laminated MDF using avocado, pine and mahogany veneers decreased the hygroscopic properties and increased its resistance to the drywood termites' attacks. The increasing com-ply's density was influenced by the used veneer type. Most linear expansion decreased, yet two com-ply types were found increased. These happened both in parallel and perpendicular direction, yet statistically insignificant. The decreasing TS after laminated with veneers showed that the com-ply's dimensional stability increased. SWL also increased up to $37.8 \%$ in the PMI com-ply type, while the internal bonding was the same with MDF.

\section{REFERENCES}

Ayrilmis, N. 2008. Effect of compression wood on dimensional stability of medium density fiberboard. Silva Fennica 42(2): 285.

Ayrilmis, N., Akbulut, T., Yurttaş, E. 2017. Effects of core layer fiber size and face-to-core layer ratio on the properties of three-layered fiberboard. BioResources 12(4): 7964-7974.

Biblis, E.J., Grigoriou, A., Carino, H. 1996. Flexural properties of veneer-overlaid OSB composite panels from southern yellow pine. Forest Products Journal 46(4): 59-62.

BPS 2017. Statistik Produksi Kehutanan (Statistic of Forestry Production) 2017. Sub-Directorate of Forestry Statistic (Ed). BPS-Statistics Indonesia, Jakarta, Indonesia.

BSN 2006. 01-7207-2006: Uji ketahanan kayu dan produk kayu terhadap organisme perusak kayu (The durability test of wood and wood products against 
Linear Expansion and Durability of a Composite Boards (MDF Laminated Using Three Selected Wood Veneers) against Drywood Termites

wood-deterioration organisms). BSN (Badan Standarisasi Nasional) (National Standardization Agency of Indonesia): 12.

Büyüksarı, Ü., Hiziroglu, S., Akkılıç, H., Ayrılmış, N. 2012. Mechanical and physical properties of medium density fiberboard panels laminated with thermally compressed veneer. Compos Part B-Eng 43(2): 110-114.

Cahyono, T.D., Darmawan, W., Novriyanti, E. 2020. Performance of samama (Anthocephalus macrophyllus) LVL based on veneer thickness, juvenile proportion and lay-up. Wood Material Science \& Engineering 15(3): 155-162.

Cahyono, T.D., Massijaya, M.Y., Iswanto, A.H., Yanti, H., Anisah, L.N. 2019. The flexural properties of medium density fibreboard overlaid with veneer from three species of wood. IOP Conf. Ser.: Earth and Environmental Science 374: 012061.

Cahyono, T.D., Masssijaya, M.Y. 2007. Laminated Veneer Lumber (LVL): Sejarah, Penggunaan dan Teknologi (LVL: History, Utilization and Technology). Fakultas Kehutanan IPB (Faculty of Forestry, Bogor Agricultural University) Press, Bogor, Indonesia.

Cahyono, T.D., Wahyudi, I., Priadi, T., Febrianto, F., Darmawan, W., Bahtiar, E.T., Ohorella, S., Novriyanti, E. 2015. The quality of 8 and 10 years old samama wood (Anthocephalus macrophyllus). Journal of the Indian Academy of Wood Science 12(1): 22-28.

Cristescu, C. 2006. Bonding of laminated veneers with heat and pressure only. International Conference on Environmentally-Compatible Forest Products: 20/09/2006-22/09/2006, Fernando Pessoa University.

FAO 2016. 2015 Global Forest Products Facts and Figures. Food And Agriculture Organization of The $\mathrm{UN}$.

Ganev, S., Cloutier, A., Beauregard, R., Gendron, G. 2007. Linear expansion and thickness swell of MDF as a function of panel density and sorption state. Wood and Fiber Science 37(2): 327-336.

Garcia, C.M., San Pablo, M.R., Bianchi, S., Pichelin, F. 2018. Resistance of fibreboards made of milled coconut husk and bonded with tannin against insects and fungi under Philippine conditions. International Wood Products Journal 9(3): 99-107.

Gaspersz, V. 1991. Metode Perancangan Percobaan Untuk Ilmu-Ilmu Pertanian, Ilmu-Ilmu Teknik, dan Biologi. CV. Armico, Bandung, Indonesia.

Hiziroglu, S., Bauchongkol, P., Fueangvivat, V., Soontonbura, W., Jarusombuti, S. 2007. Selected properties of medium density fiberboard (MDF) panels made from bamboo and rice straw. Forest Products Journal 57(6): 46-50.

Hiziroglu, S., Suchsland, O. 1993. Linear expansion and surface stability of particleboard. Forest Products Journal 43(4): 31.

Iswanto, A.H., Aritonang, W., Azhar, I., Fatriasari, W. 2017. The physical, mechanical and durability properties of sorghum bagasse particleboard by layering surface treatment. Journal of the Indian Academy of Wood Science 14(1): 1-8.

Jocham, C., Schmidt, T.W., Wuzella, G., Teischinger, A., Kandelbauer, A. 2011. Adhesion improvement of powder coating on medium density fibreboard (MDF) by thermal pre-treatment. Journal of Adhesion Science and Technology 25(15): 1937-1946.

JSA 2003. A 5905-2003: Fibreboard. Japanese Industrial Standards. Japanese Standard Association (JSA), Tokyo, Japan.

Karlinasari, L., Nawawi, D., Widyani, M. 2010. Kajian Sifat Anatomi dan Kimia Kayu Kaitannya dengan Sifat Akustik Kayu. Bionatura 12(3): 110-116.

Kılıç, M., Burdurlu, E., Aslan, S., Altun, S., Tümerdem, Ö. 2009. The effect of surface roughness on tensile strength of the medium density fiberboard (MDF) overlaid with polyvinyl chloride (PVC). Materials \& Design 30(10): 4580-4583. 
Tekat Dwi CAHYONO $\cdot$ Hikma YANTI $\cdot$ Laela Nur ANISAH • Muh Yusram MASSIJAYA $\cdot$ Apri Heri ISWANTO

Komariah, R.N., Massijaya, M.Y. 2015. PhysicalMechanical Properties of Glued Laminated Timber Made from Tropical Small-Diameter Logs Grown in Indonesia. Journal of the Korean Wood Science and Technology 43(2): 156-167.

Milagres, E.G., Barbosa, R.A.G.S., Caiafa, K.F., Gomes, G.S.L., Castro, T.A.C., Vital, B.R. 2019. Properties of Particleboard Panels Made of Sugarcane Particles With and Without Heat Treatment. Revista Árvore 43(5).

Miyamoto, K., Suzuki, S., Inagaki, T., Iwata, R. 2002. Effects of press closing time on mat consolidation behavior during hot pressing and on linear expansion of particleboard. Journal of Wood Science 48(4): 309-314.

Nuryawan, A., Alamsyah, E.M. 2017. A review of isocyanate wood adhesive: a case study in Indonesia. Applied Adhesive Bonding in Science and Technology: 73-90.

Rowell, R.M. 1998. The state of art and future development of bio-based composite science and technology towards the 21 st century.

Seo, Y.-R., Kim, B.-J., Lee, S.-Y. 2019. Effects of Nanoclay and Glass Fiber on the Microstructural, Mechanical, Thermal, and Water Absorption Properties of Recycled WPCs. Journal of the Korean Wood Science and Technology 47(4): $472-485$.

Septiana, D., Febrianto, F., Arinana 2014. Keawetan Alami Dua Belas Jenis Kayu dari Hutan Pendidikan Gunung Walat terhadap Serangan Rayap (Natural Durability of 12 Woods Species Grown in Mount
Walat Forest Education against Termites Attacked). Thesis, IPB University, Bogor(ID).

Taghiyari, H.R., Norton, J. 2014. Effect of silver nanoparticles on hardness in medium-density fiberboard (MDF). iForest 8(5): 677-680.

Taskirawati, I., Agussalim, A., Baharuddin, B., Suhasman, S. 2019. Characteristics of the Cement Board Using CO2 Injection Technology from Wood and Non-Wood Species. IOP Conference Series: Materials Science and Engineering, IOP Publishing.

Tsoumis, G. 1991. Science and technology of wood. Structure, properties, utilization. Van Nostrand Reinhold, New York, USA.

Wu, Q., Suchsland, O. 1996. Linear expansion and its relationship to moisture content change for commercial oriented strandboards. Forest Products Journal 46(11/12): 79-83.

$\mathrm{Xu}$, W., Suchsland, O. 1997. Linear expansion of wood composites: A model. Wood and Fiber Science 29(3): 272-281.

Yanti, H., Massijaya, M.Y., Cahyono, T.D., Novriyanti, E., Iswanto, A. H. 2019. Fundamental Properties of Composite Board Made with Oriented Strand Board and Three Different Species of Veneer. Journal of the Korean Wood Science and Technology 47(2): 239-248.

Zhang, Y.-h., Huang, Y.-x., Ma, H.-x., Yu, W.-j., Qi, Y. 2018. Effect of Different Pressing Processes and Density on Dimensional Stability and Mechanical Properties of Bamboo Fiber-based Composites. Journal of the Korean Wood Science and Technology 46(4): 355-361. 